\title{
CONCEPTS AND BASIS OF INTERNATIONAL RELATIONS IN ISLAMIC GOVERNMENT PERSPECTIVE
}

\author{
Zarul Arifin ${ }^{1}$ \\ Sri Sudono Saliro ${ }^{2}$
}

\begin{abstract}
After the Muslims spread Islam throughout the universe, the contact of the Muslims with the a jam nations had entered a new chapter in international relations. Territorial boundaries displayed in plain sight do not make Muslims limit themselves in interactions between countries. The relationship between Muslims and other nations is inspired by the teachings of Islam itself, which requires Muslims always to maintain peace between Muslims and internal and external Muslims. Islam has laid the foundation of peace in international relations with one main stipulation that Muslims are not allowed even to interfere in the internal affairs of other nations. The methodology used in this research is to use a literature review approach, namely reviewing the literature related to this research. The purpose of this study is to reveal how Islam regulates relations with non-Muslims, both in the territory of Islam and with the region of non-Muslims, as exemplified by the Prophet Muhammad how he established links with the Quraish infidels through the Hudaybiyah agreement
\end{abstract}

1 Assistant Professor, Islamic Institute of Sultan Muhammad Syafiuddin Sambas, Jalan Raya Sejangkung No.126 Sambas Higher Education Area, Indonesia, zarularifin89@gmail.com

2 Assistant Professor, Islamic Institute of Sultan Muhammad Syafiuddin Sambas, Jalan Raya Sejangkung No.126 Sambas Higher Education Area, Indonesia, srisudonosalirofh@gmail.com 
and with the other unbelievers such as the agreement contained in the Medina Charter. The results of this study revealed that since the time of the Prophet Muhammad, SAW had taught to have good relations with other nations, and it was passed on by the companions of the Prophet, even regarding today how each country should maintain good relations with other countries and of course it can be profitable for both countries.

Keywords: concepts, international relations, Islamic Governance

\section{INTRODUCTION}

One of the fields of socio-political science that seems to have not been taken seriously in Islamic studies in international relations. The author rarely finds a complete discussion of international relations from the perspective of Islamic politics. Especially if the study is approached from the point of view of the Quran. In Islamic studies, this political term is usually equated with the theme of siyāsah; etymologically, it means arranging things in a way that brings benefit. ${ }^{3}$ In terms of fiqh, it is known as siyāsah fiqh or siyāsah Sariyah, which is an institution to regulate state affairs and the ummah of the people following Islamic law so that benefits are realized and avoid harm. ${ }^{4}$ In more detail, the fields of study are siyāsah dustüriyah (laws), siyāsah Aaliyah (economics), siyāsah dawliyah international relations). The study of international relations in siyassah figh, although it is a relatively old theme, is a product of classical and medieval Islamic treasures.

So that practically, this problem becomes a complex problem when faced with the concept of a nation-state adopted by several Muslim countries in the modern era. In short, current international law can be defined as a set of rules and principles that regulate relations between states and states, between states and legal subjects other than states, and between non-state legal issues and one another. "International law may be defined as that body of law which is composed for its greater part of the principles and rules of conduct which states feel bound to observe, and therefore, do commonly observe in their relations with each other, and which also includes: (a) the rules of relating to the functioning of international institutions or organizations, their relations with States and individuals; and (b) certain rules of law relating to individuals and non-State entities so far as the rights or duties of such individuals and non-

\footnotetext{
3 Ibn Manzūur, Lisān al- 'Arab (Bayrūt: Dār al-Ṣādir, 1968), 108.

4 'Abd al-Wahhāb Khalaf, al-Siyāsah al-Sharī'ah (Qāhirah: Dār al-Anșār, 1977), 4.
} 
State entities are the concern of the international community". 5 Theoretically, International Relations has presented several major theories in this field of study or science by paying attention to at least five fundamental social values usually guarded by the State: security, freedom, order, justice and welfare. These are authentic values for human beings which they must protect or guarantee in any way. ${ }^{6}$

The spectrum of international relations in Islam revolves around war and peace as well as the international relations of Islamic countries with other Islamic countries and non-Muslim countries, which gave birth to the Islamic political concept of Dār al-Islām (peaceful area), Dār al-'Ahd (treaty area) and Dār al-Harb (region of war). However, the idea then experiences a blurry conception if it is relevant to the historical reality of Muslims today, especially the relationship between Muslim countries, such as the war between Iran and Iraq, the Iraqi invasion of Kuwait, which was assisted by America and its allies in liberating Kuwait. This historical reality shows that the three dār concepts mentioned above cannot explain the wars between these Islamic countries. And even more ironic is the existence of an Islamic state that has entered into a joint defence agreement precisely to fight Islamic countries.

It can even be said that the three dār concepts are the result of normative studies about the socio-political, historical journey of Muslims, which cannot explain the historical reality that occurred during the early Islamic period. For example, the event known in history under the name al-fitnah al-kubrā. Namely the assassination of the Third Caliph Uthman bin Affān, the Shiffin war between Ali bin Abi Talib and Talhah's troops. The conflict between Zubayr and 'Aisha, the Prophet's wife, the battle between Ali ibn Abi Talib and Muawiyah ibn Abi Sufyan, the war between Shia Ali and the Khawārij. Similarly, the Abbasid revolutionary movement overthrew the Umayyad dynasty. ${ }^{7}$ During the Abbasid dynasty, another place found the continuation of the Umayyad dynasty, namely the Umayyad Caliphate in Andalusia. The historical journey of the Islamic dynasties did not escape the various rebellions launched by the Muslims themselves. And finally, these dynasties experienced weakness and destruction until Mustafa Kemal Attāthur abolished the caliphate system. $^{8}$

5 J.G. Starke, Introduction to International Law, 8th ed. (London: Butterworths, 1977), 76.

6 Robert Jackson \& Georg Sorensen, Pengantar Studi Hubungan Internasional, trans. Dadan Suryaputra (Yogyakarta: Pustaka Pelajar, 2005), 3.

7 Norcholis Majid, Kaki Langit Peradaban Islam (Jakarta: Paramadina, 1997), 138.

8 Binnaz Toprak, Islam dan Perkembangan Politik di Turki (Yogyakarta: Tiara Wacana, 1999), 1-2. 
So the division of territory stated in the three concepts mentioned above can be said to be irrelevant in today's political phenomena in the modern world, especially in the context of international relations in Islam. In addition, it can also be said that the historical reality and the historical reality of Muslims at the end of the 20th century are increasingly showing tensions with their normative area where Muslims and Islamic countries are in western power and or American hegemony. And, of course, he is not able to carry out his roles in international relations.

Even though this historical reality has become the hegemony of Muslims today, this cannot deny the urgency of a state in Islam because the State is a symbol of international relations in Islam, the State is also a place for the actualization of religious teachings which are communicated in the form of human relations, both in the context of religion as well as in the form of global connections on an international scale.

Referring to the factors that have been stated above, this journal will examine the nature of international relations in Islam, the concept and basis of international relations in Islam, how international relations exist in Islamic government and the urgency of the State in realizing international relations in Islamic governance.

\section{DISCUSSION}

\section{The Nature of International Relations in Islam}

Researchers on international relations differ, as they argue that the science of international relations includes all relations between countries. This opinion makes the scope of international relations extensive. At the same time, Schwarzenberger stated that the science of international relations is a part of sociology specializing in studying global society. Another opinion sees that the scope of the science of international relations is narrower than the first opinion. This opinion emphasizes the political aspects of relations between countries to their influence on the countries' foreign policies concerned. Among the definitions of international relations in this narrow sense is the science of international relations as an academic subject, mainly concerned with political relations between nations. ${ }^{9}$

$9 \quad$ Charles A. Mc Alland, Theory and The International System, trans. Mien Joebhār \& 1shak Zahir (Jakarta: Rajawali, n.d.), 6-7. 
From the definitions above, it can be understood that international relations in a general sense include various relations other than political relations between countries, such as economic, social, cultural relations and so on. Meanwhile, the specific definition only emphasizes the aspects of political relations which are manifested in foreign policy. Therefore. In this context, international relation is a part of political science.

The essence of international relations in Islam is as the embodiment and actualization of $d a^{\prime}$ wah Islamiyah to implement religious teachings in the context of the State as a forum for the $d a$ 'wah. Even though according to Abd Raziq, Islam does not recognize the institution of the caliphate because the issue of government and state functions has absolutely nothing to do with religion. All of that, concerning politics. Religion does not recognize such an institution, but neither does it deny its existence, nor does it command nor prohibit it. Everything is up to the considerations of reason, experience and prevailing political rules. In his book, among other things, it is stated that the Prophet was only sent to convey religion without intending to establish a state. The Prophet had no worldly power, State or government, nor did he establish a kingdom in a political sense or anything similar to an earthly kingdom. ${ }^{10}$

The view expressed by 'Ali ibn 'Abd al-Raziq was challenged and criticized by several other Muslim figures by giving different opinions and ideas about the importance of the State as a forum for formally preaching religious teachings, as stated by Ahmad Salabiy that the divine message what the Prophet conveyed to humanity paid attention to spiritual and worldly affairs because, in addition to being a belief, it is also a rule. Muhammad SAW became the first Islamic community leader; he held two religious positions in charge of receiving revelations and conveying them and an administrative (worldly) position as the holder of power (head of State). ${ }^{11}$

The two views above are very different in assessing the prophetic function of Muhammad in leading the Islamic State of Medina. Everything can be described as in the discourse of the realization of Religion and the State. The first group argues that religion does not need to be regulated by the State; let it develop according to its teachings and be carried out by each of its adherents.

Buya Hamka is commenting on the importance of the State's role in the context of actualizing religious teachings. Humans need the State because of practical considerations; therefore, the State, in the view of Islam, is a tool to

\footnotetext{
10 'Alī Ibn 'Abd al-Raziq, al-Islām wa Ușūl al-Hukm (Miṣr: n.p., 1926), 10.

11 Ahmad Syalabiy al-Mujtama', al-Islami, trans. Muhtar Yahya (Surabaya: Ahmad Nubhan, 2002).
} 
implement the laws of truth, equality and justice for the people. ${ }^{12}$ The existence of the Islamic State of Medina is proof of how the Prophet Muhammad carried out his dual functions, on the one hand as a prophet who had to convey his religious message to Muslims, and on the other side as the head of government who had to regulate and pay attention to relations between its citizens and relations between Medina countries and outside countries. ${ }^{13}$ The Medina Charter is a charter of a peace treaty that can unite differences, tribes, groups, and religions to live together and protect each other. ${ }^{14}$ The formation of the Medina Charter cannot be separated from various problems, conflicts, and the interests and traditions of the community. The policies contained in the Medina Charter were the answer to the issues at that time. The studies that researchers have carried out have different points of view and accuracy on the Medina Charter. However, no one has been able to explain in depth the events of the Medina Charter by using conflict analysis tools.

Ali Bulac said that the formation of the Medina Charter could not be separated from the existence of a census of the composition of the Medina population, which was still simple. ${ }^{15}$ The presence of this census or mapping indicates that the transfer of the Prophet Muhammad SAW and the policies implemented have been carefully considered. This policy cannot be separated from the existence of a power that can be used in regulating the life of the people of Medina. ${ }^{16}$ The parties to the conflict or the parties to peace can be identified as in his opinion H. A. R. Gibb, stated in Medina the Prophet Muhammad SAW. as arbitrator (peacemaker) and peacemaker (peacemaker). ${ }^{17}$ Position Muhammad Saw. as a peacemaker in the Medina Charter, he cannot be separated from his position, position, and supportive family line. It does not appear suddenly without a solid reason to be a peacemaker. Muhammad has a lineage from Yastrib from the mother's family, from Abdul Munthalib's grandfather as Muhammad's protector and has substantial power in the

12 Hamka, Islam: Revolusi Ideologi dan Keadilan Sosial (Jakarta: Pustaka Panjimas, 1984), 101.

13 Faisal Ismail, Dinamika Kerukunan Antar umat Beragama (Bandung: Rosdakarya, 2014), 9-10.

14 M. Mukhsin Jamil, Mengelola Konflik Membangun Damai (Semarang: Walisongo Media Center, 2015), 49.

15 Ali Bulac, 'The Madina Document,' in Liberal Islam: A Sourcebook, ed. Charles Kurzman (New York: Oxford University Press, 1998), 170.

16 Khalil Abdul Karim, Hegemony Qurasiy; Agama, Budaya, Kekuasaan, trans. M. Faisol Fatawi (Yogyakarta: LkiS, 2002), 24.

17 H.A.R. Gibb, Islam A Historical Survey (London: Oxford University Press, 1978), 18. 
Quraysh family. ${ }^{18}$ The Aus and Khazraj tribes before Muhammad's Hijrah had also made Muhammad a peacemaker in the events of the artificial war (the war for the springs).

Ibn Khaldun says the same thing. In his political thought, he argues that the role of religion is vast in establishing a great state. According to him, every country with a large and large power must be based on religion, whether broadcast by the Prophet (nubuwwah) or the call for truth (da'wah al-haq) ${ }^{19}$

Seeing the importance of the role of the State as stated by the scholars above, according to the author, one form of international relations in the modern world is through the principle of the sovereignty of a state because the role of the State, in this case, is to fight for the interests of its people in the context of the relationship between the state and citizens. Fight for state sovereignty in the context of international relations. Referring to this argument, the State's existence in Islam cannot be denied because the concept of international relations becomes the implementation of the meaning of God's commandment to get to know each other.

\section{Principles and Basics of International Relations in Islam}

To find out the principles and basis of international relations in Islam can be traced in various Qurans and the Sunnah of the Prophet. Among the verses that are relevant to the discourse of international relations are Q.S. al-Hujurat, 49:13;

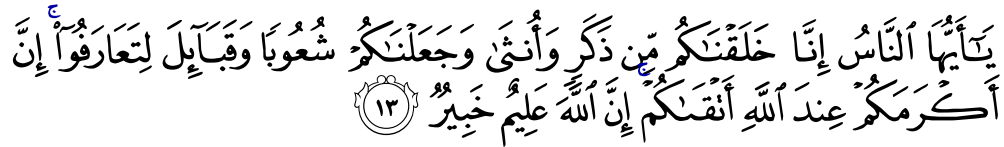

"O humanity, indeed, We created you from a male and a female and made you into nations and tribes so that you may know one another. Verily, the most honourable of you in the sight of Allah is the one who is most pious among you. Verily Allah is AllKnowing, All-Knowing."

The content of verse 13 above states that humans only consist of male and female types. The union of the two types of human beings makes them many,

18 Mun'im Sirry, Kontroversi Islam Awal: Antara Mazhab Tradisionalis dan Revisionalis (Bandung: Mizan, 2013), 208.

19 A. Rahman Zainuddin, Kekuasaan dan Negara: Pemikiran Politik Ibn Khaldun (Jakarta: Gramedia Pustaka Utama, 1992), 164-165. 
and then they live in nations and tribes to know each other, know each other, and help each other and need each other to achieve a noble and noble life. The glory of man in the sight of Allah SWT lies in the degree of purity to Him.

If the content of the verse is linked with the previous verses, it can be said that verse 13 above is relevant to human relations (including believers) with other humans. In other words, the content of this verse sets out the basic principles of human relations. This is understood from the appeal addressed to all humanity. While the range of the previous four verses, namely Q.S. alHujurat, 49: 9-12, put forward the instructions for the association between fellow believers. Thus verse 13 above suggests how the building of interaction between humans and other humans. According to the author of the paragraph above, it is relevant to the study of international relations from the context of such an understanding.

The first term etymologically contains the meaning that seems to be something or benign and forgetful and shaken. The first meaning is rooted in words hamzah, nun and sin. While the second and third meanings are rooted in the letters nun, sin and yes and the letters nun, wa and sin. According to Muin Salim, the meaning of seemingly something and tame refers to two aspects of humans, namely the outward physical aspect and the psychological aspect. Second aspect. This is relevant to the nature of friendliness, pleasure and knowledge, as shown in one form of the derivation of the root words hamza, nun and sin, namely anasa-yu'nisu and anisa-ya'nisu. From the connotation of the psychological meaning, it can be understood that humans are social beings and cultural beings. It is said to be a social creature because humans have a natural tendency always to gather together. It is being said to be an artistic creature because humans have the ability and potential to have the knowledge and create civilization. The connotation of social beings is relevant to verse 13 above, while the purpose of cultural beings is relevant to Q.S. al-Nahl, 16: 78. ${ }^{20}$

The word al-nas is found in the Quran 240 times. ${ }^{21}$ According to Fazlhur Rahman, the use of the word in the Quran refers to humans individually. Whole (absolute). Rahman's view can be justified considering in verse 13 above, the term al-nas is followed by a term indicating the type of human being, namely male (testicle) and female (untha). This means that both men and women are al-Nas. From this point of view, it can be emphasized that all humans, whether male or female, who later become pluralistic nations and tribes, are bound by

20 Muin Salim, Kekuasaan Politik dalam al-Quran (Jakarta: IAIN Syarif Hidayatullah, 1989), 103-105.

21 Fu'ad 'Abd al-Baq̄̄, Mu 'jam Mufakhras li Alfāz al-Qur'ān (Bayrūt: Dār al-Fikr, n.d.), 726-728. 
one common bond, namely the bond of humanity. Therefore, men, women, tribes and nations are equal in terms of society.

The second term is only found once in the Quran. The term shu' $u b$ etymologically contains two primary opposite meanings, namely dispersal and gathering. At the same time, the term qaba ' $i l$ has the primary meaning of something dealing with something else. Lexicologically, the first term refers to the meaning of a group of people who gather based on ties of descent, language and mutually agreed rules. Al-Ashfahani said that this word refers to the meaning of people who are supposed together in one life. Lexicologically, the second term refers to a branched meaning, such as a group of people bound by the exact needs, desires and circumstances; groups of people who share one father and ancestor; types of animals and plants: clothing patches. Ibn Mansyur said the meaning of qaba ' $i l$ is a member of the nation associated with the exact needs and desires. While al-Ashfahani interprets it as a group of people who are gathered, some of them accept others.

Quraish Shihab said that the term shu' $u b$ is the plural form of the word sha' $b$. This word is used to designate several qabilah, which are usually translated into tribal meanings that refer to one grandfather. Qabilah also consists of many family groups called 'imarah, and this one consists of many groups called bathn. Underneath the bathn, there are fakhz until finally, they arrive at the smallest family group. Thus it can be understood that the term $s h u$ ' $u b$ has a more comprehensive human quantity than qabilah. Quraish seems to see the difference between the two terms regarding the number of people who gather in them.

It's different only with the view of Ali Shari'a. In a sociological context, Ali Shariati said that the terms sha'b (mufrad form of shu'ub), shu'ba and inshi 'ab, all refer to the same root. This means that the human race on this earth is divided into various branches ( $s h u$ ' $b a h)$, and each chapter is a separate nation. This means that they separate themselves into multiple groups. And that group is a branch of the human group.

Furthermore, Shariati said that the term qabilah is the oldest and even older than the term nation. According to him, the qabilah is a collection of individuals who have the same goal under the auspices of the gabilah. The most potent element uniting individuals in such a society is a common goal, namely an ideal for becoming united.

The phrase consists of the letter lam ta 'lìl, which connotes purpose and the verb ta'ärafū, which has the wazan tafa-'ala-yatafa-'alu indicating a reciprocal meaning of knowing each other. This work is taken from the word 


\begin{abstract}
'Arafa, which contains two primary purposes: First, part of something follows the other function continuously. Second. Quiet and calm. From these two primary meanings, said Ibn Faris, the word al-ma 'rifat or al-Irfan is formed, as in the clause " "arafa fulan fulanan 'irfānan wa ma "rifah" meaning so and so knowing so and so well. Suppose the content of this central meaning is linked with the phrase lita 'árafiu above. In that case, it can be said that the concept of lita 'ârafü connotes the sense of knowing each other, which paraphrase calm and peace as opposed to restlessness. Thus the idea of lita 'ārafü connotes the importance of the concept of amar ma 'rüf and nahi munkar. ${ }^{22}$ So the purpose of getting to know each other, as stated in the verse above, is an effort to show each other something that can produce calm and peace instead of disturbing. In other words, a joint effort to uphold what is $m a$ ' $r \bar{u} f$ and prevent what is evil in the life of the world community. Based on the description above, it is understood that the basic concepts and principles of international relations in Islam can be found in, among others, Q.S. al-Hujurāt and Q.S. al-Mumtahanah. Among the basic principles of international relations in Islam are the following;
\end{abstract}

\title{
a) The Same Principle of Humanity
}

According to what can be understood from verse 13 of Surah al-Hujurat above, this is one of the primary and essential in international relations. This conception is understood from using the word al-nas which refers to humans consisting of male and female types. Then the two types of humans were made into several shu' $u b$ and qabā'il. Thus, some of the shu'ub and qaba' 'il are firmly bound by the bonds of humanity. Because one of the dimensions of humans is as social beings, as stated above, the interaction between one human or group of humans with humans and other human groups is absolute. This is intended to meet human needs both as individuals and as a community. In this interaction between human groups, an essential glue is needed that can bind the interaction relationship. And the adhesive bond in question is the bond of human humanity owned by every individual and human community, be it the shu' $u b$ or $q a b \bar{a}$ 'il groups.

Thus it can be emphasized that in the view of the Quran (at least according to the author), human community relations, both on a small scale and an international scale (world community or international relations), must be built on the basis and principle that all humans are the same. There is no difference in terms of his humanity.

22 Ibn Fāris, Abū Husayn Aḥmad Ibn Zakariyā, Mu 'jam Maqāyis al-Lughah (Bayrūt: Dār al-Fikr, n.d.), 759. 
This fundamental principle then has implications for the form of universal human thought that is not separated from geographic-territorial (transterritorial-geographical) as it is known in the form of state thought and nationalism politics. This may be one of the reasons why the Quran does not use the term daulah (State) in designating human social groups as a further elaboration of the above principles but uses other terms, such as the terms $s h u^{\prime} u b$ and $q a b \bar{a}^{\prime} i l$ and various other times. This is interesting for further analysis. But that is not the place in this paper. But the author wants to put forward one reason (which may be considered and discussed further), namely the concept of $s h u$ ' $u b$ is broader than statehood. It is said so because the idea of $s h u^{\prime} u b$ is not separated by geographic-territorial, likewise with ethnicity (qabail). In addition, from a sociological point of view, the adhesive attached to the terms shu' $u b$ and $q a b \bar{a}$ ' $i l$ is more robust than that of the state.

\section{b) Principle of Recognition of the Existence of Pluralism, Not Pluralism}

The plurality of human socio-political groups is illustrated by using the words shu' $u b$ and $q a b \bar{a}$ 'il in verse 13 of Surah al-Hujurat above. And Allah SWT himself as Khaliq who has made this plurality the acknowledgement of a sya'b and qabilah for the existence of a majority of sya'b and qabila has implications for the depreciation of the nature of racism or the recognition of a higher feeling of a social group over other social groups based on race, ethnicity. Nation, culture, language and descent. Primarily when the recognition of plurality is based on the awareness that all humans are the same as stated in the first principle. Thus, being higher and not feeling the need for other social groups can be neglected. This will give birth to arrogance or feeling superior and high and looking at others as lower and contemptible. On the other hand, the concept of lita 'ârafü is more advanced.

Based on the above description of the principle of recognizing the plurality of social groups, it is hoped that the arrogance of racialism will be eradicated in various social interactions of particular human communities on an international scale. In this way, the opportunities for social conflicts on a national and international scale can be contained. In this context, the lita 'ârafiu movement as the third principle occupies a very urgent position, as will be described below. 


\section{c) The Principle of the Lita' $\bar{a} r a f \bar{u}$}

The essence of the principle of this movement is a joint movement in the context of realizing tranquillity and peace as well as collaborative efforts to prevent evil deeds that can create anxiety and damage to the world community. This movement is the primary goal of the existence of a plurality of human social groups, as described above.

Thus, it can be said that the content of the meaning of the concept of lita 'ârafū about international relations is a joint movement to create peace and harmony in the life of the world community and prevent various anxiety and destruction. Thus, human existence and humanity can be universally preserved. This movement is in line with the content of the Quranic verse, which emphasizes the command to work together to create perfect virtue and the prohibition of cooperating in all forms of evil and hostility that can create universal human damage. As emphasized in the Quran:

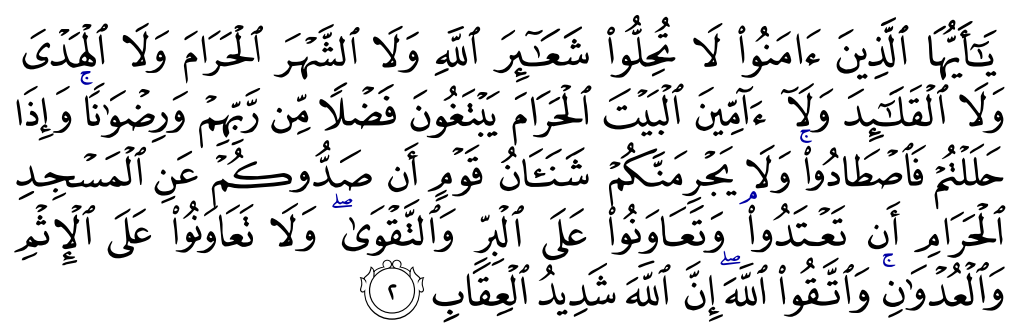

"O you who believe, do not violate the symbols of Allah and do not violate the honour of the forbidden months, do not (disturb) hadya animals and qalaid animals, and do not (also) disturb people who visit the Temple. At the same time, they seek grace and pleasure from their Lord, and when you have completed the pilgrimage, it is permissible to hunt. And do not hate (you) for a people because they prevent you from the Masjid al-Haram, encourage you to do wrong (to them) and help you in (doing) righteousness and purity, and do not help in sin and transgression. And fear Allah, verily Allah is severe in punishment.

(Surah al-Mā'idah, 5: 2)

From this verse 2, the clause relevant to the discussion is a clause that points to meaning and help you in (doing) virtue and piety. And do not help in sin and transgression and fear Allah SWT, verily Allah SWT is severe in punishment. The content of this clause is a series of Allah's calls to believers, which contains prohibitions, namely the prohibition of violating Allah SWT and the honour of the forbidden month, the ban on disturbing had-ya and 
qaldid animals - the ban on alarming people who are on a pilgrimage to seek bounties and The pleasure of Allah SWT and the prohibition of hatred for a people cause acts of injustice and injustice.

Even though the prohibitions in verse 2 are aimed at those who believe, according to the author, the content of the clauses relevant to this discussion, including the ban on doing injustice and injustice to a social group, is only driven by hatred of a people, the scope of which is universal considering the messages that follow. The transmission of prohibition is versatile.

Based on the description of this third principle, it can be emphasized that what is meant by the concept of lita 'ârafü about international relations is a joint movement to uphold virtue and truth and prevent evil and evil to create peace and tranquillity in the international community and protect the international community from sin and evil. Its destruction. And this is the duty and responsibility of the international community to make it happen. The cooperation movement between fellow human beings is universal without exception, including between Muslims and non-Muslims. This principle is in line with the assertion in the Quran:

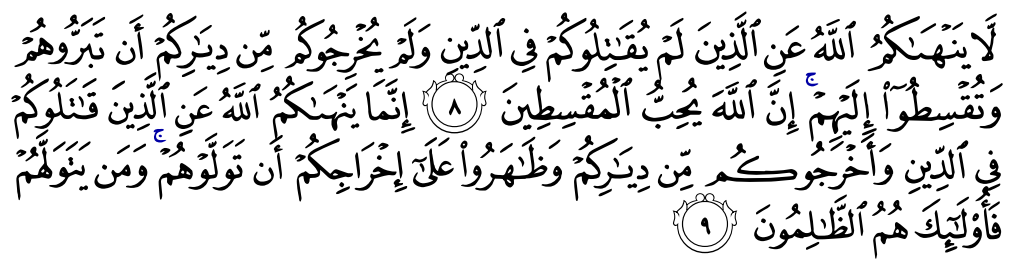

"Allah does not forbid you to do good and do justice to those who do not fight you because of religion and do not (also) expel you from your country. Verily, Allah loves those who act justly. Indeed, Allah only forbids you to make as your friends those who fight against you because of religion and expel you from your country and help (others) to banish you. And whoever takes them as friends, then they are the wrongdoers."

(Surah al-Mumtahanah, 60: 8-9)

The content of these last two verses very clearly states that my good deeds and fair conduct are ordered to people who believe in anyone, both fellow believers and non-Muslim community groups, as long as they (non-Muslim communities) do not fight against your group-Min based on religion and do not carry out imperialist movements. Thus war in Islam is allowed only to be directed against other social groups that are hostile to and fighting against the believers. 
Therefore, it is very unwarranted to view that Islam is a religion of the sword and accuse Muslims that their relationship with other people is built on the blade's power. And Islam is spread by war or the sword; it is said so because the war in Islam can only be carried out when Muslims are in a position to be fought first to maintain their existence, dignity and honour. Strictly speaking, Muslims are not aggressive socio-political groups. Even in the view of the Quran, the wars carried out by Muslims against other socio-political groups that carry out aggressive movements against them are still limited by not being allowed to take actions that go beyond the limits. As emphasized in the Quran:

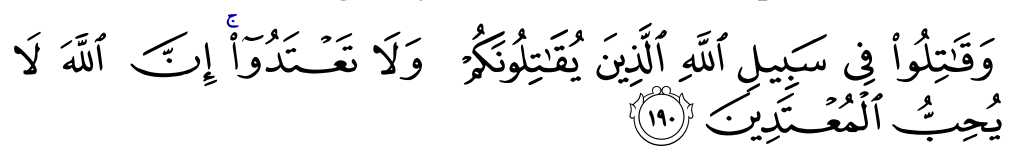

"And fight in the way of Allah those who fight you, (but) do not transgress, for Allah does not like those who disobey."

(Surah al-Baqarah, 2: 190)

And when the war is over and victory is in the hands of the Muslims, the defeated social group is free to choose a religion without any coercion. As emphasized in the Quran:

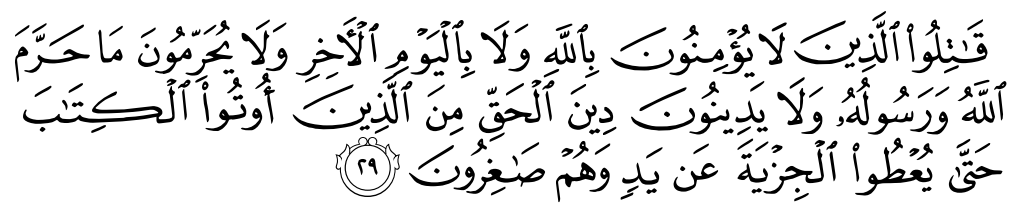

"Fight those who do not believe in Allah and do not (also) in the Last Day, and they do not forbid what Allah and His Messenger have forbidden and do not believe in the true religion (the Religion of Allah), (i.e. those) who the book was given to them until they paid the jizyah obediently while they were in a state of submission."

(Surah al-Tawbah, 9: 29)

In the last verse, it is evident that when non-Muslim social groups submit to Islam and they do not want to embrace Islam; they will never be forced, only they are required to pay jizyah to get protection from Islamic rulers and then their rights and obligations are the same as Muslims as Muslim citizens. On the other hand, those who choose Islam as their religion have the same rights and responsibilities as other Muslims.

From the contents of the two verses in Surah al-Mumtahanah above, other principles of international relations are also found, namely the direction of 
realizing international world peace and the focus of upholding universal justice in the world. On the other hand, war can only be carried out to defend oneself and then create peace. In other words, war can only be carried out if a solution is no longer found and the fight is carried out only to maintain world peace. Therefore, Islam does not recognize imperialism. This concept was implemented by the Prophet when he was the head of state in Medina.

\section{The Form of International Relations in the Tradition of Islamic Government}

To find out whether international relations have been implemented in the Islamic system of government, the author tries to explore the basis of international relations that the Prophet carried out as head of state in Medina. Like a true statesman, the Prophet Muhammad carried out these international relations based on the principles of tasamuh or tolerance towards the citizens of Medina consisting of Islam, Judaism and Christianity, and other countries and governments. The tasamuh attitude shown by the Prophet is based on and inspired by the teachings of Islam as a religion that carries the instructions of compassion. $^{23}$

The Prophet's tolerant attitude in building a pattern of relations between the citizens of Medina was arranged in such a way in the Medina Charter. The people of Medina at that time felt freedom and independence. ${ }^{24}$ In addition, the non-Muslim community (Jews and the rest of the Arab tribes who previously did not want to accept Islam) also felt this freedom and independence through the Medina Charter, which was created and enforced by the Prophet. ${ }^{25}$ These agreement letters include the Prophet's agreement with the Jews and Christians, the peace agreement between the Prophet and several tribes, a letter of security guarantee, and a letter calling for $d a$ ' wah to tribal chiefs, kings, leaders, and others. All of these data enable us to confirm that the nature (diplomacy) and the letters of the Prophet describe an unusual diplomatic activity and international relations. ${ }^{26}$

23 Ibn Fāris, Abū Husayn Aḥmad Ibn Zakariyā, Mu jam Maqāyis al-Lughah, vol. 3 (n.p.: Mușțafā al-Bābī al-Ḥalābī, 1971), 65.

24 Departemen Pendidikan Nasional, Kamus Besar Bahasa Indonesia, $3^{\text {rd }}$ ed. (Jakarta: Balai Pustaka, 2005), 204.

25 Mahmud Yunus, Kamus Arab-Indonesia (n.p.: n.p., n.d.), 178.

26 Ahmad Warson al-Munawwir, Kamus Terlengkap Arab Indonesia (Surabaya: Pustaka Progressif, 1987), 657. 
The feeling of freedom of the citizens of Medina is due to the pattern adopted by the Prophet in carrying out the relationship between the Prophet as head of State and Christian Jews as a component of the citizens bound by the universality of the Prophet's tolerance ${ }^{27}$ when the fact shows that the Jewish leaders are still trying to destroy Islam from within. ${ }^{28}$ Still, the Prophet did not show hostility towards them. Even the Prophet prioritized the realization of peace and harmony, including the Jews. ${ }^{29}$

The facts above show that the Prophet, in running the government of the Medina state, was very concerned about the internal relations of his citizens and international relations with other countries by establishing tolerance as the basis. For example, in the social field, the Prophet's tolerance was shown by promoting peace towards several religious, ethnic and racial communities in Medina and outside Medina, even against non-Muslims, even though the Prophet still invited them to take responsibility together in protecting the city of Medina. ${ }^{30}$ Another social event driven by the spirit of tolerance was the agreement of the Hudaibiyah agreement, namely when the Prophet wanted to perform the pilgrimage but was always prevented by the polytheists. ${ }^{31}$

This Hudaibiyah agreement seems to be detrimental to the Muslims, but the deal benefits the development of Islam. The Prophet's attitude in accepting the Hudaibiyah agreement was a tolerant attitude based on a policy that prioritized patience because the Prophet did not want bloodshed and this Prophet's approach was not weakness but based on Allah's instructions as stated in the Quran which reads as follows:

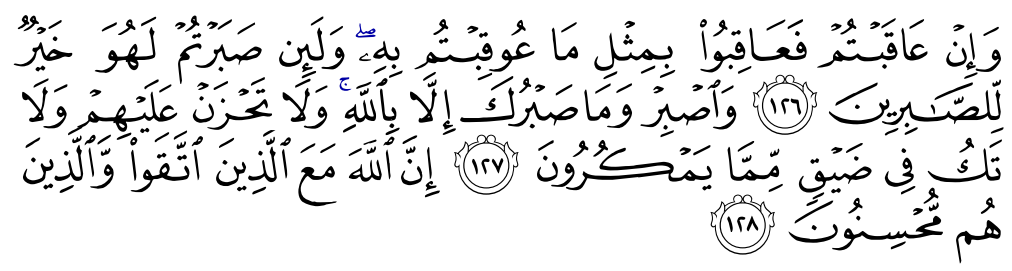

\footnotetext{
27 Ḥafīz Aḥmad, al-Idārah fì 'Aṣr al-Rasūl (Miṣr: Dār al-Salām IIIT, 2000), 128.

28 Munawir Syadzali, Islam dan Tata Negara: Ajaran Sejarah dan Pemikiran (Jakarta: Universitas Indonesia Press, 1990), 10.

29 Ibn Hishām, Sīrah al-Nabī Șallallahu 'Alayh wa Sallam, vol. 2 (Qāhirah: Dār alFikr, 1981), 121.

30 Sted Mahmudun nasir, Islam Its Concepts \& History (New Delhi: Kitab Bhavan, 1981), 103.

31 Aḥmad Ibrāhim al-Sharīf, Dawlah al-Rasūl fí al-Madīnah (Kuwayt: Dār al-Bayān, 1972), 245-246.
} 
"If you give recompense, then repay with compensation equal to the torment inflicted on you. But if you are patient, indeed, that is better for those who are patient. Be patient (O Muhammad), and your patience is not except with the help of Allah and do not grieve for them (unfaithfulness) and do not be stifled by what they deceive. Verily, Allah is with those who are pious and those who do good."

(Surah al-Naḥl, 16: 126-128)

From the verse above, it is understood that the Prophet waged war to restore security and order so that the people could live in peace and then to enforce law and justice so that everyone could receive equal protection and rights. ${ }^{32}$ Regarding this war, Abu Zahrah said that fighting in Islam is to fend off attacks, to secure $d a$ 'wah and to prevent oppression because of religion. Islam justifies war after visible signs of slander or attacks occur. If conflict is unavoidable, then a commander first offers several options against the enemy, namely converting to Islam, entering into an agreement not to disturb the Muslims and the last resort is war. ${ }^{33}$

Therefore, the pattern of international relations established by the Prophet in dealing with prisoners of war at Badr was to warn his companions to treat them (prisoners of war) as well as possible. ${ }^{34}$ Because among the companions of the Prophet, some wanted the prisoners of war to be killed and asked for a ransom. Still, in the end, the Prophet agreed with his companions that the prisoners of war be released with a ransom even one of them, namely Abu Azza, was released without ransom because he promised not to fight Islam. Still, he broke his promise and returned to fight Islam at the battle of Uhud, so that he was killed at that time.

In the political field, the Prophet showed an attitude of tolerance in carrying out international relations towards the religion of the kings who accepted the Prophet's invitation to convert to Islam. Muqawqis, a Coptic ruler in Egypt, received the Prophet's messenger with all respect, he even sent a gift to the Prophet, and the Prophet accepted it. It was good even though Muqawqis did

32 Afsal al-Rahman, Muhammad as Military Leader, trans. Anas Siddik (Jakarta: Bumi Aksara, 1991), 19.

33 Muhammad Abū Zahrah, al-Alaqāt al-Dawliyyat fì al-Islām, trans. Muhammad Zein Hasan (Jakarta: Bulan Bintang, 1973), 119-120.

34 Muhammad Husayn Haikal, Hayaat Muhammad, trans. Ali Audah (Jakarta: Pustaka Litera Antar Nusa, 1994), 264. 
not convert to Islam. Likewise, King Najasy of Abyssinia also received well the letter of the Prophet inviting him to convert to Islam; even some sources say that he converted to Islam. King Najasy also sent a letter to the Prophet asking the Muslims in Abyssinia to be returned to Medina.

These agreement letters contain sentences which if observed, have high language. Its nature is evident, dense in content, straightforward, full of honesty and authority, and far from deceit. According to Hafidz Ahmad 'Ajjaj al Karmi in his Book al-Idārah fì 'Așr al-Rasūl notes that several historical sources of scholars have also mentioned several names of ambassadors or diplomats who were sent by the Prophet to kings, accompanied by a letter containing an appeal to them to Islam among them;

1. Dihyah bin Caliph al-Kalbi was sent to the Roman Emperor. ${ }^{35}$

2. Abdullah bin Hudzafah As Sahmi was sent to the King of Persia. ${ }^{36}$

3. Amr bin Umayyah ad Dhamri who was sent to King Najasyi.

4. Hatib bin Abi Balta'ah was sent to King Al Muqauqis in Egypt. ${ }^{37}$

5. Amr bin Al Ash to the rulers of Oman Jifar and Ayyad.

6. Sulait bin Amr was sent to Tsumamah bin Utsal and Haudzah bin Ali. Two kings of Yamamah.

7. Al-A'la Al Hadrami, sent to Al Munzir bin Sawa King of Bahrain

8. Suja ' bin Wahab al Asadi was sent to Al Harith bin Abdi Kalal Al Himyari, a Takhum King in Sham.

On another occasion, the Prophet al Amin also sent several ambassadors (sifarah) to several tribes. The Prophet sent Zhabyan bin Mursyid ad Dausi to Bani Bakr bin Wa'il, Jarir bin 'Abd Allah al-Bajali to al-Kala' bin Nakur, also Amr bin 'Umayyah ad Dhamri to Musayilamah al-Kadzab and others. The envoy's dispatch occurred at the end of the sixth year and the beginning of the seventh year after the Hudaibiyyah peace. The most significant result of these letters sent by the Prophet formed the international opinion that Islam is a religion that comes to all human beings.

35 Muḥammad bin Jarīr bin Kathīr al-Ṭabarī, Tarīkh al-Rusūl wa al-Mulūk, vol. 2 (Bayrūt: Dār al-Turāth, 1387), 646.

36 'Abd al-Shāfì Muḥammad 'Abd al-Lațīf, al-Sirah al-Nabawiyah wa al-Tarīkh alIslāmī (Miṣr: Dār al-Salām, 1428), 155.

37 Abū 'Amrū Khalīfah bin Khayyāt, Tārikh Khalīfah bin Khayyāth, ed. Akram Ḍiyā' al-'Umarī (Bayrūt: Dār al-Qalam, 1397), 79. 
In the election of ambassadors, the Prophet never left the conventions and customs applied to modern diplomacies, such as; change of ambassadors, beautiful posture, good looks, and high ability. ${ }^{38}$ Modern diplomacy requires one's attention to appearance. So a diplomat does often appear with a flawless face and stature. Long before that, the Prophet had set an example of how a person should choose an ambassador to represent his country. Sulaymān alRuhayli, in his study of the Diplomacy of the Islamic State and the Byzantine Roman State in his Book As-Sifarât al-Islâmiyyah ilâ Bilad Byzantine, explains this. He emphasized that the election made by the Prophet is crucial because the first thing that will be seen in the context of diplomacy is a person's stature and face. That's because they are a representation of the Muslim Ummah and the religion that the Prophet brought. For example, why did the Prophet send his friend Dihyah al-Kalbi? Because he was an attractive man in his time. In the narration, it is stated that Jibril often met the Prophet in a form similar to Dihyah Al Kalbi. ${ }^{39}$

This also applies to other friends such as Mu'ādh bin Jabal, Abu Musa al-Ash'ari, 'Abd Allah bin Hudzafah, Amr bin al-'Aș, etc. They are the most intelligent friends, the most handsome, the most beautiful of speech, the most skilful of speech, and the strongest of arguments. In addition, they are famous for having high knowledge, skilled in correspondence and administration amid society at that time. Another requirement in sending diplomatic ambassadors is fluency in speaking. ${ }^{40}$ This was done by the Prophet and also the caliphs of the Muslims after him. Mūsā Shahhin al-Ashin, Fatḥ al-Mun 'im Sharh Șaḥ̄h Muslim, quotes the Prophet's story where he once sent a friend Hatib bin Abi Balta'ah to the empire of Christian King Muqauqis in Egypt. After Hatib's friend explained diplomacy and dialogue to the king and conveying Islamic messages, King Muqauqis was amazed by the sentences delivered with great authority. King Muqauqis's interest in Islam was evident from his attitude and even gave appreciation to Hatib's friend as the envoy (diplomat) with famous words; (It is true what you say). You are full of wisdom and come from a messenger who is also full of wisdom). From this meeting, we know that King Muqauqis gave a gift to the Prophet in Sahaya Mariyah al Qibtiyah, who later married him and would later give birth to a son named Ibrahim.

38 Sulaymān al-Ruhaylī, al-Sifarāt al-Islāmiyyah ilā Bilād Bizantiyyah (Riyāḍ: Maktabah al-Tawbah, 1414H), 30.

39 Al-'Asqalānī, Shihāb al-Dīn Aḥmad Ibn 'Alī Ibn Hajar, al-Iṣābah fì Tamayyiz al-Sahāabah, ed. Shaykh 'Adīl Aḥmad 'Abd al-Mawjūd, et al. (Lebanon: Dār alKutub al-'Ilmiyyah, 1995), 321.

40 Mūsā Shahhin al-Ashin, Fath al-Mun im Sharh Șaḥ̄h Muslim (Mișr: Dār alShuruq, 2002), 513. 
Thus Islamic diplomacy has been carried out and strengthened its position since the time of the Prophet. The Prophet as the leader of the State, has shown high diplomatic activities and is full of exemplary. The Islamic politics built by him indicates that Islam can create a new paradigm in terms of relations between nations and countries. The power of Islam brought by the Prophet was even able to change the political situation in the world. At that time, the mecca of civilization was always focused on Roman, and Persian cultures now have an alternative. The Roman and Persian civilizations, which became references in various fields of human life, could not survive with the Islamic movement that emerged quickly and unstoppably.

The Prophet's attitude shows how Muhammad had an attitude of tolerance in the socio-religious life created by the Prophet in building the people of Medina. Therefore, it is not surprising that the Prophet succeeded in building a heterogeneous Medina community with various adherents of different religions and beliefs. ${ }^{41}$ This is the pattern of relationships shown by the Prophet in the form of religious tolerance at that time so that the Prophet's character as a spiritual leader and the community of the State has made Islam a unifying religion so that society is in a harmonious social reality and has succeeded in achieving the highest social integrity so that Islam is easily spread throughout the region. Arabic, Byzantine and Persian. ${ }^{42}$

The paradigm of the relationship between the nation and the State in Islam is also built on the principles of peace, not war as the principle of imperial power and great kings before the advent of Islam. Islam tends to prioritize aspects of peace and the enforcement of arguments (da'wah). War is an action that can be taken later if the stages of peace have been taken but are not accepted. Indeed, there are differences in the views of Islamic scholars regarding the origin of the law of relations between countries in Islam (Islamic State v. Kafir State). Muhammad Habas stated that the scholars differed in opinion in three parts; ${ }^{43}$ First, the statement says that the original relationship between the two countries is al-harb (war). This is stated by the fiqh scholars of the four schools of thought from the Hanafiyah, Mālikiyah, Shāfi'iyyah, and Hanābilah circles. This opinion is also followed by contemporary 'ulamā': Shaykh Abū al-A'la al-Mawdūdī, Sayyid Quṭb, and Shaykh Salah al-Haydan

41 Joachim Wach, Sociology of Religion (London: The University of Chicago Press Ltd, 1971), 36.

42 W. Montgemeri Watt, Islam and The Integration of Society (London: Routledge \& Kegan Paul Ltd, 1970), 5.

43 Muḥammad Habas, al-Islām wa al-Diplumasiyyah: Qirā'ah fì al-Qim alDiplumasiyyah fì al-Islām (Arabiya: Aspir Printing Press, 2013), 25-24. 
rahimahulullah. Second, the statement states that the original relationship between an Islamic State and an infidel state is al-salam (peace). War will only occur if there is an attack from another party, the kuffar's efforts to interfere with the religion of Islam, and other causes. As mentioned by scholars such as; Imam al-Awza' $\overline{1}$, Imam al-Thawrī, Imam Ibn Taymiyyah, Imam Ibn Qayyim and followed by contemporary scholars such as; Shaykh Wahbah al-Zuhaylī, Shaykh Abū Zahrah, Shaykh Mahmūd Shaltut, and others. Third, the opinion states that the original law is $d a$ 'wah. Namely, $d a$ 'wah carried out following the conditions that occur in an area or region.

\section{CONCLUSION}

The study of relations between nations is not a new thing in the academic tradition of Islamic civilization. The study of relations between countries had become an official scientific discipline in the Islamic world at the beginning of the middle of the second century Hijri under the name Siyar. The Islamic perspective in the study of International Relations has a unique foundation and way of thinking different from Western philosophy. Ontologically, the Islamic perspective believes that reality can be both physical and metaphysical. Epistemologically, the Islamic perspective believes that revelation is an essential source of knowledge besides reason, heart and senses. As for axiologically, the Islamic perspective considers that science is not value-free. Science must be used following the essential purpose of human existence in this world. The benefits of a scientific study are seen academically and practically and must be viewed religiously, namely the benefits of getting a human closer to the Creator. The essence of international relations in Islam is to actualize religious teachings in the context of the relationship between citizens within the state and the relationship between citizens and the state with other countries. Therefore, the State's existence in Islam is essential, and its existence cannot be denied. The basis of international relations in Islam is found in various verses of the Qur'an and al-Sunnah, as well as state administration practices are shown by the Prophet. The principles of international relations in Islam include the principle of equality among human beings and the direction of pluralism and the focus of lita 'a rafü, the principle of international peace and the principle of upholding universal justice.

\section{REFERENCES}

'Abd al-Shāfì Muḥammad 'Abd al-Laṭif, al-Sirah al-Nabawiyah wa al-Tarīkh al-Islāmī (Miṣr: Dār al-Salām, 1428). 
'Abd al-Wahhāb Khalaf, al-Siyāsah al-Sharī'ah (Qāhirah: Dār al-Anșār, 1977).

'Alī Ibn 'Abd al-Raziq, al-Islām wa Ușūl al-Hukm (Miṣr: n.p., 1926).

Al-‘Asqalānī, Shihāb al-Dīn Aḥmad Ibn 'Alī Ibn Hajar, al-Iṣābah fì Tamayyiz al-Ṣaḥābah, ed. Shaykh 'Adīl Aḥmad 'Abd al-Mawjūd, et al. (Lebanon: Dār al-Kutub al-'Ilmiyyah, 1995).

A. Rahman Zainuddin, Kekuasaan dan Negara: Pemikiran Politik Ibn Khaldun (Jakarta: Gramedia Pustaka Utama, 1992).

Abū 'Amrū Khalīfah bin Khayyāt, Tārikh Khalīfah bin Khayyāth, ed. Akram Diyā’ al-'Umarī (Bayrūt: Dār al-Qalam, 1397).

Afsal al-Rahman, Muhammad as Military Leader, trans. Anas Siddik (Jakarta: Bumi Aksara, 1991).

Aḥmad Ibrāhim al-Sharīf, Dawlah al-Rasūl fì al-Madīnah (Kuwayt: Dār alBayān, 1972).

Ahmad Syalabiy al-Mujtama', al-Islami, trans. Muhtar Yahya (Surabaya: Ahmad Nubhan, 2002).

Ahmad Warson al-Munawwir, Kamus Terlengkap Arab Indonesia (Surabaya: Pustaka Progressif, 1987).

Ali Bulac, 'The Madina Document,' in Liberal Islam: A Sourcebook, ed. Charles Kurzman (New York: Oxford University Press, 1998).

Binnaz Toprak, Islam dan Perkembangan Politik di Turki (Yogyakarta: Tiara Wacana, 1999).

Charles A. Mc Alland, Theory and The International System, trans. Mien Joebhār \& lshak Zahir (Jakarta: Rajawali, n.d.).

Departemen Pendidikan Nasional, Kamus Besar Bahasa Indonesia, $3^{\text {rd }}$ ed. (Jakarta: Balai Pustaka, 2005).

Faisal Ismail, Dinamika Kerukunan Antar Umat Beragama (Bandung: Rosdakarya, 2014).

Fu'ad 'Abd al-Baq̄̄, Mu 'jam Mufakhras li Alfāz al-Qur'ān (Bayrūt: Dār alFikr, n.d.).

H.A.R. Gibb, Islam A Historical Survey (London: Oxford University Press, 1978).

Hafīẓ Aḥmad, al-Idārah fì 'Aṣr al-Rasūl (Miṣr: Dār al-Salām IIIT, 2000).

Hamka, Islam: Revolusi Ideologi dan Keadilan Sosial (Jakarta: Pustaka Panjimas, 1984). 
Ibn Fāris, Abū Husayn Aḥmad Ibn Zakariyā, Mu 'jam Maqāyis al-Lughah, vol. 3 (n.p.: Muștafā al-Bābī al-Ḥalābī, 1971).

Ibn Fāris, Abū Husayn Aḥmad Ibn Zakariyā, Mu jam Maqāyis al-Lughah (Bayrūt: Dār al-Fikr, n.d.).

Ibn Hishām, Sìrah al-Nabì Șallallahu 'Alayh wa Sallam, vol. 2 (Qāhirah: Dār al-Fikr, 1981).

Ibn Manzūur, Lisān al- 'Arab (Bayrūt: Dār al-Ṣādir, 1968).

J.G. Starke, Introduction to International Law, $8^{\text {th }}$ ed. (London: Butterworths, 1977).

Joachim Wach, Sociology of Religion (London: The University of Chicago Press Ltd, 1971).

Khalil Abdul Karim, Hegemony Qurasiy; Agama, Budaya, Kekuasaan, trans. M. Faisol Fatawi (Yogyakarta: LkiS, 2002).

M. Mukhsin Jamil, Mengelola Konflik Membangun Damai (Semarang: Walisongo Media Center, 2015).

Mahmud Yunus, Kamus Arab-Indonesia (n.p.: n.p., n.d.).

Muhammad Abū Zahrah, al-Alaqāt al-Dawliyyat fì al-Islām, trans. Muhammad Zein Hasan (Jakarta: Bulan Bintang, 1973).

Muhammad bin Jarīr bin Kathīr al-Ṭabarī, Tarīkh al-Rusūl wa al-Mulūk, vol. 2 (Bayrūt: Dār al-Turāth, 1387).

Muhammad Habas, al-Islām wa al-Diplumasiyyah: Qirā'ah fì al-Qim alDiplumasiyyah fì al Islām (Arabiya: Aspir Printing Press, 2013).

Muhammad Husayn Haikal, Hayaat Muhammad, trans. Ali Audah (Jakarta: Pustaka Litera Antar Nusa, 1994).

Muin Salim, Kekuasaan Politik dalam al-Quran (Jakarta: IAIN Syarif Hidayatullah, 1989).

Mun'im Sirry, Kontroversi Islam Awal: Antara Mazhab Tradisionalis dan Revisionalis (Bandung: Mizan, 2013).

Munawir Syadzali, Islam dan Tata Negara: Ajaran Sejarah dan Pemikiran (Jakarta: Universitas Indonesia Press, 1990).

Mūsā Shahhin al-Ashin, Fatḥ al-Mun 'im Sharḥ Ṣaḥịh Muslim (Miṣr: Dār alShuruq, 2002).

Norcholis Majid, Kaki Langit Peradaban Islam (Jakarta: Paramadina, 1997).

Robert Jackson \& Georg Sorensen, Pengantar Studi Hubungan Internasional, trans. Dadan Suryaputra (Yogyakarta: Pustaka Pelajar, 2005). 
Sted Mahmudun Nasir, Islam Its Concepts \& History (New Delhi: Kitab Bhavan, 1981).

Sulaymān al-Ruhaylī, al-Sifarāt al-Islāmiyyah ilā Bilād Bizantiyyah (Riyāḍ: Maktabah al-Tawbah, 1414H).

W. Montgemeri Watt, Islam and The Integration of Society (London: Routledge \& Kegan Paul Ltd, 1970). 